R.Z. Fakhrislamov

\title{
COMPLEX PROTECTION OF VERTICAL STAINLESS STEEL TANKS
}

КОМПЛЕКСНАЯ

ЗАЩИТА

PEЗЕРВУАРОВ

ТИПА РВС

Рассмотрена проблема обеспечения безопасности хранения нефти и нефтепродуктов в стальных резервуаpax. Приведено описание защищенной патентом технологии комбинированной защиты внутренней поверхности резервуаров, направленной на обеспечение технологической, пожарной и экологической безопасности при эксплуатации, а также снижения потерь нефтепродуктов за счет естественных испарений, что является отдельной проблемой.

Ключевые слова: резервуар вертикальный стальной, коррозия металлоконструкций, защита от коррозии, полимерные теплоизоляционные материалы, полиуретановое покрытие.

Существующая во всем мире тенденция увеличения числа и размеров резервуарных конструкций и их парков приводит к повышению ответственности и опасности этих сооружений [1]. Обеспечение их надежной и безопасной эксплуатации является актуальной проблемой.

Резервуары для хранения нефти и нефтепродуктов, в частности резервуары вертикальные стальные (РВС), должны соответствовать требованиям технологической, технической, физико-химической и экологической безопасности, быть пожаровзрывобезопасными.

Наиболее опасным и непредсказуемым процессом разрушения конструкций резервуаров является коррозия металла.

Одним из возможных путей снижения риска аварий или минимизации их последствий является применение комбинированных систем защиты, предусматривающих комплекс мероприятий, обеспечивающих надежность безопасной эксплуатации резервуаров.

Особого внимания заслуживают характерные недостатки металлических конструкций крыш резервуаров, которые проявляются при их эксплуатации, а именно:

склонность к коррозионным повреждениям конструктивных элементов при воздействии газовоздушной среды хранимого продукта, что связано с наличием каркаса на внутренней поверхности крыш и источников щелевой коррозии;
Increasing the amount of tanks and their dimensions in the whole world leads to higher reliability and risks in working with them [1]. Thus, fail-safety of these structures is a real problem.

Oil tanks, particularly, vertical stainless steel tanks (TVS), have to meet the requirements of technological, technical, physical, chemical and ecological safety, to be fire and explosion hazardous.

The most dangerous and unpredictable process of tanks destruction is metal corrosion.

One of possible ways of reducing accident risk or minimization of its consequences is the use of combined protection systems and complex of actions, providing reliability of safe tanks operation.

The special attention should be paid to the typical disadvantages of metal tank covers which become apparent in working, under following conditions:

tendency to corrosion of structure elements under the influence of air-gas medium of a stored product that is connected with the inner side framework and crevice corrosion sources;

formation of pyrophoric substances, and also falling and settling of corro- 
возможность образования пирофорных отложений, а также падение и осаждение продуктов коррозии на днище и стенку резервуара;

нарушение герметичности крыши в результате образования сквозных коррозионных повреждений.

Стратегическим решением в области проектирования и эксплуатации стационарных крыш резервуаров типа РВС является расширение применения стальных крыш с новой технологией комбинированной защиты.

Данная технология объединяет в себе защиту металла от коррозии и тепловую защиту, обеспечивающую повышение механической прочности крыши и увеличение срока эксплуатации РВС в целом. Предложенная технологическая схема защиты является «продуктом» совместных работ автора статьи, фирмы SteelPaint GmbH и СФ ООО «Коксохиммонтажпроект».

Сущность предложенной комбинированной схемы защиты заключается в следующем. После завершения строительно-монтажных работ и проведения гидравлических испытаний резервуара выполняются работы по противокоррозионной защите внутренней поверхности резервуара и крыши. Защита производится полиуретановыми однокомпонентными материалами фирмы SteelPaint GmbH. Тепловая изоляция осуществляется способом напыления горючего полимерного теплоизоляционного материала на все конструктивные элементы крыши резервуара. Применяется ППУ плотностью порядка $50 \ldots 60 \mathrm{\kappa} / \mathrm{m}^{3}$ с толщиной вспененного слоя $50 \mathrm{MM}$, что эквивалентно 100 мм минераловатной изоляции.

На поверхность ППУ изоляции наносится слой полиуретановой краски толщиной не менее 200 мкм, стойкой к нефти и летучим углеводородам.

При этой схеме ППУ заполняет нахлесточные соединения и пазухи, закрывает элементы каркаса крыш. Финишный слой полиуретановой краски защищает ППУ от воздействия газовоздушной среды. Срок службы теплоизоляции и антикоррозионной защиты соответствует расчетному сроку эксплуатации резервуара - минимум 30 лет.

Достаточная плотность и пластичность ППУ, а также хорошая адгезия к металлу с полиуретановым покрытием SteelPaint $\mathrm{GmbH}$ позволяет повысить жесткость настила при перемещении людей по его поверхности, увеличивает несущую способность крыши. Отсутствие коррозии крыши с внутренней стороны позволяет исключить припуски на коррозию и уменьшить затраты металла.

Существенное увеличение жесткости настила в комбинации с ППУ и АКЗ SteelPaint позволяет sion products on the tank bottom and walls;

cover airtightness breaking as a result of corrosion damages.

The strategic decision in TVS tank covers design and working is a wide use of steel covers with new complex protection technology.

This technology includes corrosion protection and thermal protection providing increase of cover durability and term of RVS working in general. The offered technological protection scheme is a collaborations of the author, Steel Paint $\mathrm{GmbH}$ firm and JSC "Koksokhimmontazhproyekt" Council of Federation.

The essence of the given complex protection scheme is as follows. Installation and construction works and hydraulic tests of the tank follow corrosion protection works of an inner side of tank cover. PU foam unicomponent materials of Steel Paint $\mathrm{GmbH}$ firm provide the protection. To provide heat insulation of tank cover we spray combustible polymeric heat-insulating material over the surface. PU density should be about $50 \ldots 60 \mathrm{~kg} / \mathrm{m}^{3}$ with foam layer of $50 \mathrm{~mm}$ that is equivalent to $100 \mathrm{~mm}$ of mineral wool.

PU paint layer on PU foam should not be less than 200 microns thick and oil and flying hydrocarbon resistant.

According to the scheme, PU foam fills all the joints and spaces, coats the coverings. The finishing paint layer of polyurethane paint protects PU from airgas environment. Service life of heat insulation and corrosion protection is equal to that of the tank - 30 years at least.

The sufficient density and plasticity of PU foam, and good adhesion to metal with a Steel Paint GmbH PU cover allows increasing flooring rigidity when people move on its surface, increases load-bearing capacity of a cover. Lack of cover inner side corrosion allows to exclude corrosion safety and to reduce metal expenses.

The flooring high rigidity combined with PU foam and AKZ Steel 
также расширить границы применения гладких стационарных крыш: конических крыш резервуаров объемом от 100 до $1000 \mathrm{~m}^{3}$; сферических крыш резервуаров объемом от 1000 до $5000 \mathrm{~m}^{3}$. Гладкие конические и сферические крыши разработаны и внедрены в практику отечественного резервуаростроения О.В. Дидковским.

Для таких крыш применение ППУ и АКЗ SteelPaint увеличивает их несущую способность более чем в 1,5 раза, что подтверждается проведенными лабораторными испытаниями и расчетами.

Необходимо отметить, что наиболее подвержены активной коррозии в РВС конструктивные элементы крыши, которые в условиях эксплуатации несут максимальные нагрузки в зависимости от воздействия климатических циклов (периодов). Так, например, в зимний период - снеговые нагрузки с образованием наледи, а летом - разогрев настила крыши до $60{ }^{\circ} \mathrm{C}$ за счет лучистого теплового потока Солнца.

В весенне-летний период солнечного воздействия на резервуары с нефтепродуктами процесс коррозии металла и образование пирофорных отложений происходят наиболее активно, что объясняется зависимостью скорости химической окислительной реакции от температуры: чем она выше, тем быстрее происходит процесс коррозии металла.

Другим отрицательным фактором является увеличение парциального давления в газовой фазе при разогреве металлоконструкций резервуара, что приводит к «вздутию» крыши резервуара, а с падением температуры в вечернее время или с охлаждением в период дождя - к падению давления и образованию вакуума, в результате происходит постоянное движение настила крыши. Аналогичное движение происходит при взливе и опорожнении хранимого продукта.

В осенне-зимний период на металлоконструкции крыши воздействует не только газовая фракция хранимого продукта, но и жидкая, из-за образования конденсата.

Следует отметить, что воздействие снеговых нагрузок на крышу резервуара является актуальной проблемой для многих регионов не только нашей страны, но и в мировом масштабе. При взливе нефти или нефтепродукта с положительной температурой происходит разогрев резервуара, в т.ч. и крыши. При этом таяние снегового покрова с последующим образованием наледи не только у кромки крыши, но на всей поверхности в итоге может привести к нежелательным последствиям.
Paint allows increasing the use of smooth stationary covers: conic tank covers with a capacity from 100 to $1000 \mathrm{~m}^{3}$; spherical tank covers with a capacity of 1000 to $5000 \mathrm{~m}^{3}$. O.V. Didkovskiy developed and introduced smooth conic and spherical covers in practice.

PU foam and AKZ Steel Paint increases the load-bearing capacity of the covers by more than 1.5 times that according to the laboratory tests and calculations.

It should be noted that the most corrodible elements are tank coverings, which bear the maximum loadings depending on climatic cycles (periods). In winter, it is snow and icing, and in summer - cover heating to $60{ }^{\circ} \mathrm{C}$ because of the Sun radiant heat flux.

In spring and summer period of solar impact on tanks, metal corrosion and of pyrophoric substances formation is the most active, which is explained by dependence of speed of chemical oxidizing reaction on temperature: the higher is the last, the quicker is corrosion.

Another negative factor in metal structures warming is the increase of partial pressure in a gas phase. That leads to swelling of a tank cover, and in the evening time or if it rains, when temperature drops, it may lead to pressure drop and vacuum formation and constant movement of covering. The similar movement happens during the ejection of a stored product.

In autumn and winter not only gas, but also liquid fraction, formed of condensate, of a stored product influence cover metal structures.

It should be noted that snow loading influence on a tank cover is real problem for many regions not only of our country but of the whole world. When oil or oil products with positive temperature pour out, the tank and the cover warms up. Thus, melted snow and icing may lead to negative consequences.

The most complicated physical and chemical, thermal physic and physi- 
Наиболее сложные физико-химические, теплофизические и физико-механические процессы происходят в резервуаре при пожаре. Если более полно известны параметры развития пожара в горящем резервуаре, то поведение соседнего, негорящего резервуара представляет наибольший интерес. Необходимо рассмотреть несколько вариантов состояния резервуара, а именно: степень заполнения резервуара, наличие теплозащиты и степень пожарной опасности хранимого продукта.

Предложенная комбинированная схема защиты резервуаров решает многие вопросы, связанные с эксплуатацией стальных резервуаров, однако было необходимо исследовать стойкость системы защиты на воздействие нефти.

Объектом исследования являлся теплоизоляционный материал на основе пенополиуретана различной плотности. Цели работы - изучение нефтестойкости и нефтегазопоглощаемости полиуретанового материала, используемого в качестве теплоизоляции и расширение области применения полимерных теплоизоляционных материалов в конструкциях промышленной тепловой изоляции.

В процессе лабораторных испытаний на установке (рис.) проводились исследования воздействия нефти и газовоздушной среды на стойкость и нефтегазопоглощаемость полимерных теплоизоляционных материалов, в т.ч. с покрытием из лакокрасочных материалов. cal and mechanical processes take place in the burning tank. While the consequences of the burning tank are more or less predictable, the situation with a neighboring tank is not so obvious. So it's necessary to consider some parameters of the neighboring tank condition, and namely: its occupancy, heat shield, the degree of fire risk of the contents.

The presented combined scheme of tanks protection solves many problems connected with steel tanks operation, however it was necessary to test protection system on oil influence.

The research object was the heatinsulating material based on PU foam of various density. The purpose is studying of oil resistance and oil and gas absorption of polyurethane heat-insulating materials, and increasing of polymer heatinsulating materials in industrial heat insulating structures.

The laboratory researches (fig.) tested the influence of oil and air-gas surroundings on strength and oil and gas absorption of polymer heat-insulating materials, including ones with coating of paintwork materials.

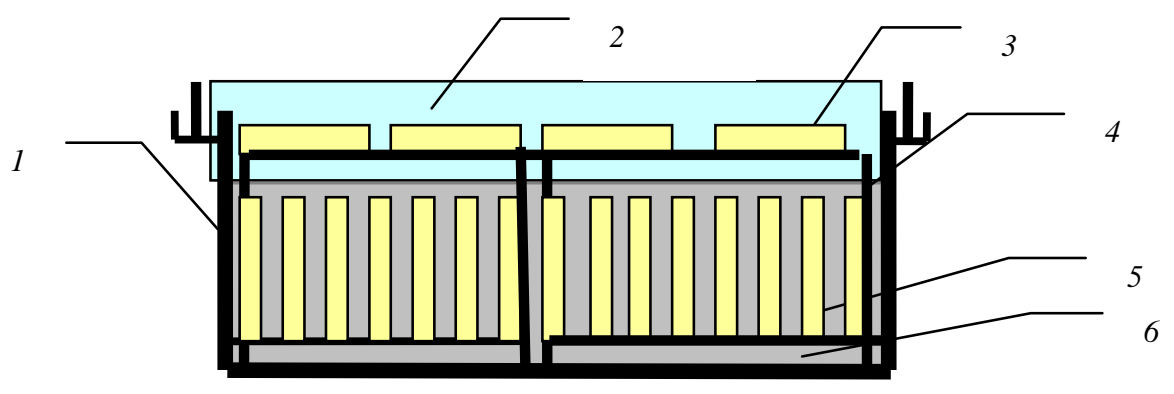

Принципиальная схема установок: 1 - металлический корпус установки с гидрозатвором и крышкой, системой подогрева и поддержания заданной температуры нефти; 2 - газовоздушное пространство; 3 - испытуемые образцы на газопоглощение; 4 - рамкадержатель образцов; 5 - испытуемые образцы в нефти; 6 - нефть

В результате исследований было установлено влияние плотности ППУ и комбинированного полимерного защитного покрытия на нефтестойкость и нефтепоглощаемость.

1. Установлено, что пенополиуретан марки ППУ-17Н и комбинированное защитное покрытие фирмы SteelPaint стойкие к воздействию нефти и газовоздушной среды нефти. Визуальные наблюдения показали, что видимых внешних изменений, таких как набухание, отслоение, размягчение и т.п., не
Installations diagram: 1 - metal casing with a water lock and a cover, heating and oil temperature maintenance; 2 - air-gas space; 3 - gas absorption testing; 4 - a frame for samples; 5 - oil tested samples; 6 - oil

The researches proved the influence of density of PU foam and the combined polymer coating on oil resistance and absorption.

1. It is established that PU foam PU foam-17N and the combined coating of Steel Paint firm are oil and air-gas resistant. Visual results showed lack of changing surface appearance, such as swelling, peeling and softening. Ap- 
было обнаружено. Внешний вид испытуемых образцов после контакта с нефтью не изменился.

2. Установлено влияние плотности ППУ на нефтепоглощаемость. Чем выше плотность ППУ, тем меньше происходит нефтепоглощение. При плотности ППУ $80 \mathrm{\kappa г} / \mathrm{m}^{3}$ и более нефтепоглощаемость отсутствует. Следовательно, необходимо при плотности ППУ $50 \ldots 60$ кг/ $\mathrm{M}^{3}$ верхний слой выпол-

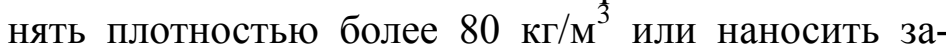
щитное ЛКМ покрытие.

3. Защитное покрытие Stelpant-PU-Combination 100 не растворяется в нефти независимо от температуры продукта и предотвращает нефтепроницаемость в поры ППУ. Внешний вид испытуемых образцов после контакта с нефтью не изменился.

4. У образцов, испытываемых в газовом пространстве лабораторной установки, приращения массы не наблюдалось. Это свидетельствует о целесообразности применения ППУ изоляции для утепления крыши резервуара с целью предотвращения коррозии, образования пирофорных отложений, а также образования наледи и снегового покрова в зимний период.

5. Применение внутренней теплоизоляции на всех резервуарах типа РВС позволит практически ликвидировать малые дыхания, что обеспечит значительное улучшение экологической обстановки и снижение пожарной опасности резервуарных парков.

\section{БИБЛИОГРАФИЧЕСКИЙ СПИСОК}

1. Типовые расчеты при проектировании и эксплуатации нефтебаз и нефтепроводов / П.И. Тугунов, В.Ф. Новосёлов, А.А. Коршак, А.М. Шаммазов. Казань, 2002.

2. СНиП 41-03-2003 Тепловая изоляция оборудования и трубопроводов.

3 .СП 61.13330.2012 Тепловая изоляция оборудования и трубопроводов. pearance of examinees of samples after contact with oil didn't change.

2. It's proved, that PU foam density influences oil absorption behaviour. The PU foam density is higher, the less is oil absorption behavior. If density is $80 \mathrm{~kg} / \mathrm{m}^{3}$ and more, there is no oil absorption. Thus, if PU foam density is $50 \ldots 60 \mathrm{~kg} / \mathrm{m}^{3}$ the top layer density should be more than $80 \mathrm{~kg} / \mathrm{m}^{3}$ or to put protective paint material.

3. Stelpant-PU-Combination 100 coating isn't soluble in oil despite product temperature and prevents permeability of oil in PU foam. Surface appearance of the tested samples after contact with oil hasn't changed.

4. There was no weight increment of the samples tested in gas space. That proves the expediency of using PU foam for heat insulation of tank cover to prevent corrosion, pyrophoric substances formation, and ice or snow coating in winter.

5. Tank inner side heat insulation will stop in-breathing and improve environmental situation. Besides, it will make possible to reduce fire danger in tank farms.

\section{REFERENCES}

1. Tugunov P.I., Novoselov V.F., Korshak A.A., Shammazov A.M. Tipovye raschety pri proektirovanii i ekspluatatsii neftebaz $i$ nefteprovodov [Routine Calculations in Oil Delivery Terminals and Oil Lines Design and Operation]. Kazan, 2002.

2. SNiP 41-03-2003. Teplovaya izolyatsiya oborudovaniya i truboprovodov [Construction Rules and Requirements 41-03-2003. Equipment and Pipe Lines Heat Insulation].

3. SP 61.13330.2012 Teplovaya izolyatsiya oborudovaniya i truboprovodov [Requirements 61.13330.2012. Equipment and Pipe Lines Heat Insulation.

Entered in edition in February 2014

Поступила в редакцию в феврале 2014 г.

About the author: Fakhrislamov Radik Zakievich, Candidate of Technical Sciences, Senior Research Worker, Associate Professor, Department of Technology, Construction Administration and Management, Mytishchi branch, Moscow State University of Civil Engineering (MGSU), 26 Yaroslavskoye shosse Moscow, 129337, Russian Federation; dekanatpgsf@mail.ru

Для цитирования:

Фахрисламов Р.3. Комплексная защита резервуаров типа РВС [Электронный ресурс] // Строительство: наука и образование. 2014. № 1. Ст. 5. Режим доступа: http://www.nso-journal.ru.

For citation:

Fakhrislamov R.Z. Kompleksnaya zashchita rezervuarov tipa RVS [Complex Protection of Vertical Stainless Steel Tanks]. Stroitel'stvo: nauka i obrazovanie [Construction: Science and Education]. 2014, no. 1, paper 5. Available at: http://www.nsojournal.ru. 